\title{
Knowledge and attitude about disabilities in leprosy: Effects of an intervention grounded on the Meaningful Learning Theory
}

\author{
Conhecimento e atitude sobre incapacidades na hanseníase: efeitos de \\ intervenção fundamentada na Teoria da Aprendizagem Significativa \\ Conocimiento y actitud en relación a las incapacidades en casos de lepra: efectos \\ de una intervención basada en la Teoría del Aprendizaje Significativo
}

How to cite this article:

Santana EMF, Brito KKG, Nóbrega MM, Antas EMV, Sousa ATO, Oliveira SHS. Knowledge and attitude about disabilities in leprosy: Effects of an intervention grounded on the Meaningful Learning Theory. Rev Esc Enferm USP. 2022;56:e20210474. https://doi.org/10.1590/1980-220X-REEUSP-2021-0474

Emanuelle Malzac Freire de Santana

D Karen Krystine Gonçalves de Brito ${ }^{2}$

(i) Matheus de Medeiros Nóbrega ${ }^{3}$

(iD) Ester Missias Villaverde Antas ${ }^{3}$

iD Alana Tamar Oliveira de Sousa ${ }^{4}$

(iD) Simone Helena dos Santos Oliveira ${ }^{3}$

${ }^{1}$ Faculdades Nova Esperança, Departamento de Fisioterapia, João Pessoa, PB, Brazil.

${ }^{2}$ Faculdades Nova Esperança, Departamento de Enfermagem, João Pessoa, PB, Brazil.

${ }^{3}$ Universidade Federal da Paraíba, Programa de Pós-graduação em Enfermagem, João Pessoa, PB, Brazil.

${ }^{4}$ Universidade Federal da Campina Grande, Unidade Acadêmica de Enfermagem, Campina Grande, PB, Brazil.

\begin{abstract}
Objective: To analyze the effects of an educational intervention in the light of the Meaningful Learning Theory on the knowledge and attitude of Primary Health Care physicians and nurses in the assessment of the degree of physical disability in leprosy. Method: An intervention study of the before-and-after type, conducted with 122 professionals (84 nurses and 38 physicians) from the Primary Health Care of João Pessoa, Paraíba, in a training course on the assessment of the degree of physical disability in leprosy. The data were collected with the research's own instrument validated and analyzed by the chi-square adherence and proportion test, with a $5 \%$ significance level. Results: There was an increase in the scores of all items of the instrument, with a statistically significant difference $(p<0.05)$ in 20 of the 32 items, with emphasis on those related to the professional's technical ability to conduct the stages of anamnesis, palpation of peripheral nerves, sensory and motor evaluation. It is also noteworthy that, after the intervention, 5 items obtained 100\% of correct answers. Conclusion: The educational intervention grounded on the Meaningful Learning Theory improved the health professionals' knowledge and attitude in the assessment of the degree of physical disability in people with leprosy.
\end{abstract}

\section{DESCRIPTORS}

Leprosy; Knowledge; Attitude; Disabled Persons; Primary Health Care.
Corresponding author:

Emanuelle Malzac Freire de Santana

Avenida Presidente Campos

Sales, 586, Apt 101, Bessa

58036-002 - João Pessoa, PB, Brazil

manumalzac@gmail.com
Received: 10/17/2021

Approved: 12/07/2021 


\section{INTRODUCTION}

Leprosy is a dermatoneurological disease that can cause physical disabilities in the face and in the upper and lower limbs, causing a series of problems, such as limitation to perform activities of daily living, reduced ability to perform work functions and restriction to participate in society, in addition to arousing stigma and prejudice ${ }^{(1-2)}$. Such disabilities can be classified in degrees ranging from 0 , when the sensory and motor functions are preserved; 1 , indicating changes in sensitivity and/or muscle strength; and 2, in the presence of visible deformities resulting from the disease, composing epidemiological indicators used for monitoring the disease ${ }^{(3)}$.

Despite the reduction in the number of cases of individuals with physical disabilities in the world scenario over the years, improvement in their management still represents a challenge for some countries, such as Brazil ${ }^{(4)}$, which holds $18.6 \%$ of all the recorded cases with disabilities in the world ${ }^{(5)}$. Of the 311,384 new cases recorded in the country between 2009 and 2018, $85,217(27.4 \%)$ already had grade 1 or 2 disabilities at the time of diagnosis.

In view of this situation, the reduction of cases diagnosed with physical disability has been listed as a priority in the "2019-2022 National Strategy against Leprosy", which requires professionals to perform early diagnosis, timely and appropriate treatment of cases and prevention of disabilities, so that cure of the disease is attained with minimal sequela $e^{(6-7)}$.

Therefore, it is necessary to ensure that these disease control activities are developed in a decentralized and integrated way to Primary Health Care (PHC) services, from an assistance and comprehensive care network and, thus, ensure access to the diagnostic and therapeutic resources close to the user's residence $^{(8-9)}$.

Considering that, in order to provide care to people with leprosy, $\mathrm{PHC}$ professionals must be qualified, having adequate knowledge about the disease and expressing attitudes in accordance with the guidelines proposed by the Ministry of Health (Ministério da Saúde, MS), it is important to investigate which knowledge and attitudes $\mathrm{PHC}$ professionals have about physical disabilities, so that weaknesses, whenever detected, are resolved through educational interventions, in order to allow them to come to successful practices.

In this direction, the use of theories focused on learning and based on the previous knowledge of the target population subsidizes the planning and development of educational interventions that value the subject as an active participant in the construction of knowledge, as it is the case of Ausubel's Meaningful Learning Theory (AMLT) ${ }^{(10)}$.

Thus, the proposal was to carry out an educational intervention on the assessment of the Degree of Physical Disability (DPD) of people with leprosy, according to the National Policy of Permanent Education in Health (Politica Nacional de Educação Permanente em Saúde, PNEPS), which aims at qualifying health professionals based on the problems and difficulties arising from their work process ${ }^{(11)}$. Therefore, the goal was to analyze the effects of an educational intervention in the light of the Meaningful Learning Theory on the knowledge and attitude of Primary Health Care physicians and nurses in the assessment of the degree of physical disability in leprosy.

\section{METHOD}

\section{Design of Study}

An educational intervention study focused on the Knowledge and Attitude constructs about the assessment of the DPD in leprosy, with evaluation before and after, based on the AMLT ${ }^{(10)}$, with PHC physicians and nurses from the municipality of João Pessoa, Paraíba, Brazil.

To guide apprehension of the Knowledge and Attitude constructs, the following concepts were adopted: (a) Knowledge: it relates to the understanding of a given subject, to the recall of specific facts, within the educational system of which the individual is part; and (b) Attitude: it concerns the emotional dimension, referring to having opinions, feelings and beliefs, constantly, about a certain object, person or situation ${ }^{(12)}$.

\section{Population}

The PHC of the municipality has 200 health teams distributed in five health districts, with a population of 392 professionals: 200 nurses and 192 physicians. To calculate the sample, a stratification procedure was performed considering a representative sampling plan of each health district, obtaining a sample of 119 professionals. In view of the possibility of sample losses in the course of the research, a percentage of $30 \%$ was increased in the number, totaling 155 professionals.

\section{Sample Selection and Definition Criteria}

The following were established as inclusion criteria: being active during the data collection period and being available to participate in the intervention; and the exclusion criterion was having a participation frequency of less than $75 \%$. The professionals were selected by the Coordination of the Leprosy Technical Area for convenience of the management to facilitate the care flow, recruited by the Health Managers of their respective Family Health Units (FHUs). 153 professionals started the intervention, with exclusion of those who were absent more than once $(\mathrm{n}=31)$, accounting for a total of 122 .

\section{Data Collection}

The intervention, entitled "Training Course for Assessing the Degree of Physical Disability in Leprosy Patients", was carried out with five groups from September to December 2019, with a workload of 20 hours, of which 16 were in-person, divided into 4 meetings, and 4 were devoted to reading texts and carrying out complementary activities.

As Ausubel did not propose any rigorously systematized model for application of the theory, the stages ${ }^{(13)}$ elaborated from Ausubel's guidelines for implementing MLT in teaching were adapted to operationalize the course, namely:

- $1^{\text {st }}$ stage: Quantitative assessment and presentation of the topic to be addressed, with prior application of the data collection instrument called "Knowledge and Attitude on the Assessment of the Degree of Physical Disability in Leprosy", consisting of 32 questions, arranged as 
Chart 1 - Items referring to the Knowledge construct of the instrument called "Knowledge and Attitude on the Assessment of the Degree of Physical Disability in Leprosy". João Pessoa, Paraíba, Brazil, 2021.

\footnotetext{
1. Do you know the Simplified Neurological Assessment (SNA) form for leprosy provided by the Ministry of Health?

2. The SNA is used to aid in the diagnosis of leprosy.

3. The SNA makes it possible to monitor the treatment of neuritis and diagnose reactions.

4. The SNA allows classifying the Degree of Disability (DD) proposed by the World Health Organization (WHO).

5. The SNA must be performed in the craniopodal sequence (head, upper limbs and lower limbs).

6. It is recommended that the SNA be performed every two months during treatment if the individual does not report complaints.
}

7. In the SNA, the assessment of sensitivity in hands and feet is performed using Semmes-Weinstein monofilaments; however, the pressure exerted by the weight of the ballpoint pen tip is similar to the pressure exerted by the purple monofilament and can be used in the absence of an esthesiometer.

8. In the SNA, the eye sensibility test can be performed without the use of tasteless floss.

9. In the SNA, dryness, wound and septal perforation are items evaluated in the nose.

10. In the SNA, the ulnar, median, radial, tibial, fibular and sciatic nerves should be investigated.

11. In the SNA, occlusion of the eyelids with and without force, as well as the presence of clefts, should be investigated during eye evaluation.

12. In the SNA, muscle strength can be graduated as strong, decreased or absent.

13. The DD proposed by the WHO assesses the existence of loss of protective sensitivity and/or alteration of muscle strength and/or visible deformity and/ or blindness as a result of neural injury.

14. DD evaluation, as proposed by the $\mathrm{WHO}$, should be determined only at the time of diagnosis and discharge due to cure.

15. After evaluation of the body segments (eyes, hands and feet), the lowest DD proposed by the WHO obtained on each side of the body should be recorded.

16. In the presence of only neural thickening, the individual should be classified with DD 0 , as proposed by the WHO.

17. In $\mathrm{DD} 0$, as proposed by the $\mathrm{WHO}$, the individual has preserved sensitivity for the $0.05 \mathrm{~g}$ monofilament (green).

18. In DD 1, as proposed by the WHO, the eyes may show signs such as lagoftalmo, ectropion, entropion and/or trichiasis.

19. Cases with at least decreased corneal sensitivity should be classified as DD 1, as proposed by the WHO.

20. Individuals with movable claw in one or both hands should be classified as DD 2, as proposed by the WHO.

21. Presentation of the first clinical case and of the sensitivity test image:

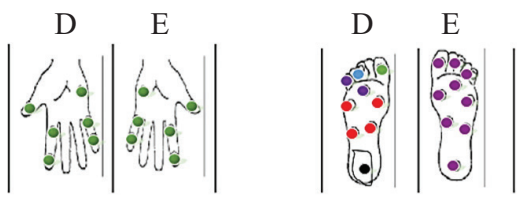

22. Presentation of the second clinical case and of the sensitivity test image:

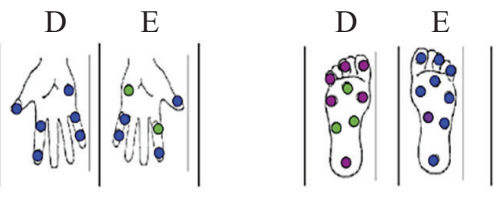

23. Presentation of the third clinical case and of the sensitivity test image:

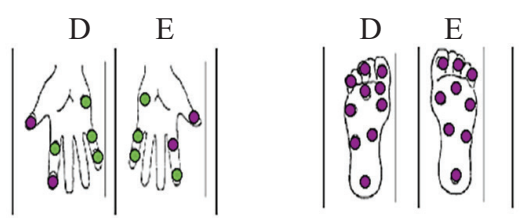

24. Presentation of the fourth clinical case and of the sensitivity test image:

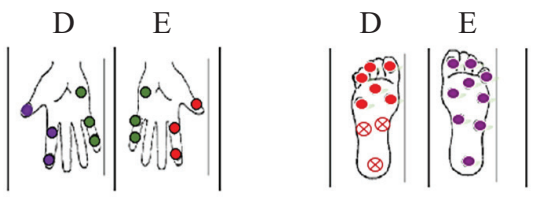

Source: Research data, 2021. 
Chart 2 - Items referring to the Knowledge construct of the instrument called "Knowledge and Attitude on the Assessment of the Degree of Physical Disability in Leprosy". João Pessoa, Paraíba, Brazil, 2021.

25. Performing the SNA and determination of the DD proposed by the WHO of leprosy patients is part of my duty.

26. Performing the SNA of leprosy patients is important to support health care planning.

27. How do you evaluate your ability to perform the anamnesis of leprosy patients through the SNA?

28. How do you evaluate your ability for palpation of the peripheral nerves of leprosy patients through the SNA?

29. How do you assess your ability to assess the sensitivity of the eyes, hands and feet of the leprosy patient through the SNA?

30. How do you assess your ability to assess the muscle strength of leprosy patients through the SNA?

31. Performing the SNA of leprosy patients at diagnosis, every three months, at discharge due to cure and/or whenever there are complaints related to the disease is:

32. Systematic neural monitoring through the SNA can prevent disabilities/problems in leprosy patients:

Source: Research data, 2021.

follows: 24 in the knowledge construct, subdivided into Simplified Neurological Assessment (SNA) (12) and Degree of Physical Disability (DPD) (12) and 8 in the attitude construct towards the DPD assessment in leprosy (Charts 1 and 2).

$-2^{\text {nd }}$ stage: Proposal of problem situations for the students to externalize their knowledge, through the opportunity of a moment of reflection on the practicalities and difficulties encountered to evaluate the DPD in PHC and discussion about the competences of the professionals in PHC to perform this evaluation.

$-3^{\text {rd }}$ stage: Proposal of problem situations to prepare the students for the presentation of knowledge, from the display of a clinical case of an individual diagnosed with leprosy and asking how to proceed with evaluation of the DPD, with generation of cognitive conflicts among the professionals by their interest to solve the problem.

$-4^{\text {th }}$ stage: Presentation of the knowledge, considering the principle of progressive differentiation, in which the general concepts must be addressed initially so that, progressively, they can be differentiated, discussing leprosy in general.

- $5^{\text {th }}$ stage: Continuation of the presentation of knowledge, based on dialog-related exposure moments about evaluation of the DPD and practical training of the SNA, taking into account the principle of integrative reconciliation to identify and explore inconsistencies between the theory and practice of PHC professionals. Theoretical and practical exercises and group discussions on clinical cases were also conducted.

$-6^{\text {th }}$ stage: Conclusion of the unit, with encouragement for discussion among the professionals about the strategies to put into practice the knowledge acquired during training.

$-7^{\text {th }}$ stage: Quantitative reassessment, with reapplication of the data collection instrument.

$-8^{\text {th }}$ stage: Closure of the course, through the participants speech on positive and negative aspects, delivery of certificates and guidance manual produced by the researcher to assist in the evaluation of the DPD of people with leprosy in $\mathrm{PHC}$.

\section{Data Analysis and Processing}

The data were analyzed in the $\mathrm{R}$ statistical software, with application of descriptive statistical techniques, such as simple absolute and percentage frequencies for the categorical variables and organization of the results in tables. The chi-square adherence and proportion tests were applied, respectively, to verify adequacy of the probabilistic model to the research data and to verify possible differences in the professionals' knowledge and attitude before and after the educational intervention, adopting a 5\% significance level $(\mathrm{p}<0.05)$.

\section{Ethical Aspects}

The research followed the ethical principles set forth in Resolution No. 466/12 of the National Health Council and was approved by the Research Ethics Committee of the Center for Health Sciences at the Federal University of Paraíba, opinion No. 3,293,760. All the participants signed the Free and Informed Consent Form.

\section{RESULTS}

There was predominance of females (87.7\%), with a mean age of 43.8 years, undergraduate Nursing (68.9\%) and in a private educational institution (51.6\%), mean training time of 20.9 years, titration related to specialization (62.3\%), belonging to Health District $1(27.9 \%)$ and with more than 10 years of practice in the FHS (47.5\%).

When asked about previous participation in leprosy training, $50 \%$ answered positively and $16.4 \%$ reported training in DPD evaluation. Regarding assistance, $66.4 \%$ stated that they never assisted people with leprosy.

Regarding the proportion of correct answers, it is observed that, after the intervention, there was an increase in all items of the instrument, which was statistically significant in 20 of the $32(62.5 \%)$ questions. Before the intervention, no item had presented $100 \%$ of correct answers and, after the intervention, this rate of correct answers was obtained in 2 items of the knowledge construct and 3 of the attitude construct, namely: $1,4,26,31$ and 32 .

Table 1 shows that in the SNA dimension of the Knowledge construct there was a statistically significant increase in the 
Table 1 - Distribution of the correct answers of the Knowledge construct related to the simplified neurological evaluation dimension before and after the educational intervention $(n=122)$. João Pessoa, Paraíba, Brazil, 2021.

\begin{tabular}{|c|c|c|c|}
\hline \multirow{3}{*}{ Questions } & \multicolumn{2}{|c|}{ Correct answers } & \multirow{3}{*}{ p-value ${ }^{a}$} \\
\hline & Pre-intervention & Post-intervention & \\
\hline & n (\%) & n $(\%)$ & \\
\hline $\begin{array}{l}\text { 1. Knowledge of the } \\
\text { form }\end{array}$ & $62(50.8 \%)$ & $122(100 \%)$ & $<0.001^{*}$ \\
\hline $\begin{array}{l}\text { 2. Purpose of use for } \\
\text { diagnosis }\end{array}$ & $12(9.8 \%)$ & $96(78.7 \%)$ & $<0.001^{*}$ \\
\hline $\begin{array}{l}\text { 3. Purpose of use } \\
\text { in the treatment of } \\
\text { neuritis }\end{array}$ & $81(66.4 \%)$ & $118(96.7 \%)$ & 0.5540 \\
\hline $\begin{array}{l}\text { 4. Purpose of use to } \\
\text { classify the DPD }\end{array}$ & $90(73.8 \%)$ & $122(100 \%)$ & 0.6574 \\
\hline $\begin{array}{l}\text { 5. Achievement } \\
\text { systematics }\end{array}$ & $80(65.6 \%)$ & $118(96.7 \%)$ & 0.7540 \\
\hline 6. Periodicity & $24(19.7 \%)$ & $103(84.4 \%)$ & $<0.001^{*}$ \\
\hline $\begin{array}{l}\text { 7. Sensitive } \\
\text { assessment of hands } \\
\text { and feet }\end{array}$ & $48(39.3 \%)$ & $116(95.1 \%)$ & $0.002^{*}$ \\
\hline $\begin{array}{l}\text { 8. Sensitive } \\
\text { assessment of the eyes }\end{array}$ & $22(18.0 \%)$ & $95(77.9 \%)$ & $<0.001 *$ \\
\hline 9. Nasal evaluation & $71(58.2 \%)$ & $111(91.0 \%)$ & $0.0405^{*}$ \\
\hline 10. Peripheral nerves & $6(4.9 \%)$ & $99(81.1 \%)$ & $0.0267^{*}$ \\
\hline 11. Eye assessment & $93(76.2 \%)$ & $120(98.4 \%)$ & 0.9330 \\
\hline $\begin{array}{l}\text { 12. Muscle strength } \\
\text { graduation }\end{array}$ & $91(74.6 \%)$ & $114(93.4 \%)$ & 0.8298 \\
\hline
\end{tabular}

Significant result: $(*)$ p-value $<0.05$.

a Proportion test.

Source: Research data, 2021.

distribution of correct answers in 58.3\% of the items, namely: knowledge of the form, purpose of use for diagnosis, periodicity of performance, sensitive evaluation of hands, feet and eyes, nasal evaluation and peripheral nerves, which deserves to be highlighted for having increased $76.2 \%$.

When analyzing the DPD dimension (Table 2), it is observed that there was a statistically significant increase in nine of the twelve items presented, which represents $75 \%$ of the total number of items. For two of the three items in which the proportion of correct answers did not show a significant increase after the intervention, there was an increase of nearly $50 \%$ in the correct answers. Additionally, the significant increase in the proportions of correct answers to the four clinical cases is highlighted, which reveals an improvement in attention and reflective ability to the characteristics of the cases and the positive effect of the intervention on knowledge regarding the DPD dimension.

Regarding attitude, a construct distributed in Table 3, it is verified that there was an increase in the proportion of correct answers in $50 \%$ of the items evaluated. It is noteworthy that, in the others, where there was an increase in proportions, although not significantly, the rates of correct answers were already high, that is, above $70 \%$ before the intervention.
Table 2 - Distribution of the correct answers in the Knowledge construct regarding the Degree of Physical Disability dimension before and after the educational intervention $(n=122)$. João Pessoa, Paraíba, Brazil, 2021.

\begin{tabular}{|c|c|c|c|}
\hline \multirow{3}{*}{ Questions } & \multicolumn{2}{|c|}{ Correct answers } & \multirow{3}{*}{ p-value } \\
\hline & Pre-intervention & Post-intervention & \\
\hline & n $(\%)$ & n (\%) & \\
\hline 13. Purpose & $87(71.3 \%)$ & $108(88.5 \%)$ & 0.2227 \\
\hline 14. Periodicity & $76(62.3 \%)$ & $115(94.3 \%)$ & $0.0297^{*}$ \\
\hline 15. Recording & $22(18.0 \%)$ & $101(82.8 \%)$ & $<0.001^{*}$ \\
\hline $\begin{array}{l}\text { 16. Classification } \\
\text { (neural thickening) }\end{array}$ & $31(25.4 \%)$ & $106(86.9 \%)$ & $0.0139^{*}$ \\
\hline $\begin{array}{l}\text { 17. Classification } \\
\text { (sensitivity of the } \\
\text { extremities) }\end{array}$ & $40(32.8 \%)$ & $114(93.4 \%)$ & 0.7338 \\
\hline $\begin{array}{l}\text { 18. Classification (eye } \\
\text { changes) }\end{array}$ & $13(10.7 \%)$ & $103(84.4 \%)$ & $<0.001^{*}$ \\
\hline $\begin{array}{l}\text { 19. Classification } \\
\text { (corneal sensitivity) }\end{array}$ & $41(33.6 \%)$ & $108(88.5 \%)$ & $0.0375^{*}$ \\
\hline $\begin{array}{l}\text { 20. Classification } \\
\text { (clawed hands) }\end{array}$ & $60(49.2 \%)$ & $118(96.7 \%)$ & 0.4477 \\
\hline 21. Clinical case 1 & $33(27.0 \%)$ & $98(80.3 \%)$ & $0.0002^{*}$ \\
\hline 22. Clinical case 2 & $15(12.3 \%)$ & $104(85.2 \%)$ & $<0.001^{*}$ \\
\hline 23. Clinical case 3 & $19(15.6 \%)$ & $107(87.7 \%)$ & $<0.001^{*}$ \\
\hline 24. Clinical case 4 & $11(9.0 \%)$ & $97(79.5 \%)$ & $<0.001^{*}$ \\
\hline
\end{tabular}

Significant result: $\left({ }^{*}\right)$ p-value $<0.05$.

a Proportion test.

Source: Research data, 2021.

Table 3 - Distribution of the correct answers for the Attitude construct before and after the educational intervention $(n=122)$. João Pessoa, Paraíba, Brazil, 2021.

\begin{tabular}{lccc}
\hline & \multicolumn{2}{c}{ Correct answers } & \\
\cline { 2 - 3 } Questions & Pre-intervention & Post-intervention & p-value \\
\cline { 2 - 3 } & $\mathbf{n}(\%)$ & $\mathbf{n}(\%)$ & \\
\cline { 2 - 3 } $\begin{array}{l}\text { 25. Professional duty } \\
\text { in carrying out the SNA } \\
\text { and DPD }\end{array}$ & $112(91.8 \%)$ & $121(99.2 \%)$ & 0.7879 \\
$\begin{array}{l}\text { 26. Importance of the } \\
\text { SNA }\end{array}$ & $114(93.4 \%)$ & $122(100 \%)$ & 0.5819 \\
$\begin{array}{l}\text { 27. Ability to perform } \\
\text { anamnesis }\end{array}$ & $7(5.7 \%)$ & $121(99.2 \%)$ & $<0.001^{*}$ \\
$\begin{array}{l}\text { 28. Ability to palpate } \\
\text { peripheral nerves }\end{array}$ & $9(7.4 \%)$ & $107(87.7 \%)$ & $<0.001^{*}$ \\
$\begin{array}{l}\text { 29. Ability to assess } \\
\text { sensitivity }\end{array}$ & $10(8.2 \%)$ & $120(98.4 \%)$ & $<0.001^{*}$ \\
$\begin{array}{l}\text { 30. Ability to assess } \\
\text { muscle strength }\end{array}$ & $19(15.6 \%)$ & $120(98.4 \%)$ & $<0.001^{*}$ \\
$\begin{array}{l}\text { 31. SNA periodicity } \\
\begin{array}{l}\text { 32. SNA purpose } \\
\hline\end{array}\end{array}$ & $90(73.8 \%)$ & $122(100 \%)$ & 0.0607 \\
\hline
\end{tabular}

Significant result: $\left(^{*}\right)$ p-value $<0.05$.

a Proportion test.

SNA = Simplified Neurological Assessment.

$\mathrm{DPD}=$ Degree of Physical Disability.

Source: Research data, 2021. 
It is also noted in Table 3 that, although before the intervention, more than $90 \%$ of the participants stated agreeing that performing the SNA and determining the DPD are part of their professional duties, less than $10 \%$ reported having the ability to perform them, with very different rates observed after the intervention.

\section{DISCUSSION}

Although most of the study participants have been working in the FHS for more than 10 years (47.5\%), which allows supposing that they know the problem involved in the care that should be provided to people with leprosy in PHC, only nearly half of the professionals (50.8\%) knew the SNA form, indicated to assess integrity of the neural function and to determine the patients' DPD, which goes against the national guidelines for the management and prevention of physical disabilities resulting from the disease ${ }^{(14)}$.

Although this percentage of professionals claimed to know the SNA form, it is verified that in the pre-intervention period, the frequency of correct answers regarding items such as peripheral nerves that should be investigated during the evaluation (4.9\%), purpose of use of the form (9.8\%), method of evaluating eye sensitivity $(18 \%)$ and periodicity of SNA performance $(19.7 \%)$ was less than expected.

After the intervention, all variables of the SNA dimension increased, noticing that the proportion of correct answers increased by $76.2 \%$ in the peripheral nerves item, $68.8 \%$ for purposes of use, $59.9 \%$ in the sensitive evaluation of the eyes and $64.7 \%$ in the periodicity with which the assessment should be carried out, resulting in significant changes in the professionals' knowledge based on the educational intervention carried out.

The same can be observed for the moment to determine the DPD, in which, when clinical cases depicting signs and symptoms identified in people with leprosy were presented, frequencies of correct answers of only 27\%, 12.3\%, 15.6\% and $9.0 \%$ were obtained in the pre-intervention for each of the 4 clinical cases, respectively.

Considering that these correct answer frequencies rose to $80.3 \%, 85.2 \%, 87.7 \%$ and $79.5 \%$ in the post-test, it is verified that, throughout the educational intervention, the professionals were able to develop clinical reasoning related to the disease, something fundamental to assist in the decision-making process and, thus, manage changes in the spaces in which they are inserted, enabling improvements in access, quality and humanization of the care provided to the population ${ }^{(12)}$. In addition to the favorable results for the knowledge construct, the relevance of the intervention can also be seen from the attitudes developed by the professionals, considering that more than $85 \%$ stated feeling capable of leading the step-by-step to carry out the SNA.

Even though, before the intervention, an expressive index of professionals believed that the SNA was part of their duties, that it supported the care planning and that it was necessary to carry it out periodically as recommended, the belief or feeling of inability to perform it among most of the participants stood as a barrier to possible future actions, even in the face of evidence of satisfactory knowledge. Attitudes like this can discourage the care of people with leprosy from the perspective of global and at the same time specialized assessment, as the attitudes adopted by professionals towards a decision process are a reflection of their beliefs and feelings, that is, of the what they believe and the feeling generated by this belief, which can exert both negative and positive influences on the care provided to people with leprosy.

The deficits in knowledge and attitude about aspects related to leprosy found in the pre-intervention can also be verified in other studies ${ }^{(7,15-16)}$, which reported presence of failures and inconsistencies between what is recommended by the MS and what is actually being carried out in PHC to control the isease in the country, which can reverberate in the emergence of complications due to the late inclusion of preventive measures.

In this context, and taking into account that only $16.4 \%$ of the professionals reported having participated in a specific course on DPD assessment in leprosy, which was even offered by the management, associated with evidence of dissociation between knowledge and attitudes already reported, the importance of expanding investments in professional training is highlighted, as well as for the managers to be concerned about offering educational strategies that address this issue, as the reduction in the number of new cases with physical disabilities is among the priorities of the disease coping strategies, both globally and in the national scope $\mathrm{e}^{(6,17)}$.

Even given the reduced number of professionals with some specific training on the topic, access to information and experiences at different times and spaces configured the knowledge and attitudes about SNA and DPD preexisting in their cognitive structures, that is, the subsumers, which acted as anchors in the meaningful learning process ${ }^{(10)}$, providing incorporation of the information made available during the educational intervention to the professionals' pre-existing cognitive structure.

With that, there were positive changes in the respondents' conception, both in knowledge and in attitude, which contributed to empowerment in the decision-making process and in problem-solving and, therefore, to the improvement of the care that had been or will be be provided to people with leprosy in PHC in the municipality.

In accordance with the theoretical framework ${ }^{(10)}$, it is believed that these changes were facilitated by the use of previous organizers, which activated the subsumers already found in the professionals' cognitive structure, but which were not being used. Previous organizers are introductory materials to be exposed to individuals before the actual material to be learned, such as the images, schemes and questions that were presented during their development, in order to act as "cognitive bridges" as they connected what the individuals already knew to what they should know.

In the literature, a number of studies support the importance of developing educational strategies for the qualification of professionals who work with leprosy. The Brazilian university developed a remote update course on disease control actions to qualify professionals in the State's PHC, which allowed the teams to deepen their theoretical knowledge, as well as monitor their performance in disease elimination actions, consolidating the course as a viable educational tool to be used by managers from other locations ${ }^{(18)}$.

A study that investigated the contribution of training courses in leprosy offered to professionals evidenced that it was 
satisfactory to have promoted theoretical and practical knowledge and enabled participants to implement actions related to the disease in their health units, thus showing the importance of the periodic maintenance of courses of this nature to fight against the disease ${ }^{(19)}$.

On the other hand, a research study that evaluated the cognitive and attitudinal skills of PHC nurses in a hyperendemic Brazilian capital city showed that, even having participated in training on leprosy, $73.3 \%$ of the participants still did not feel qualified to treat patients, especially in terms of concerns regarding diagnostic suspicion, and that only $36.6 \%$ had specific training for the prevention of disabilities, which makes it difficult to implement measures to control the disease ${ }^{(20)}$.

A study carried out in the metropolitan region of Recife-PE also identified the effectiveness of training sessions carried out on leprosy as low, revealing the need to review their methodological structure based on the problematization of work, as recommended by the PNEPS, based on theory-practice integration, in order to improve the professionals' performance with regard to early detection and timely treatment of cases $^{(21)}$.

Given the heterogeneity of the disease in the country, the arguments about the results of educational interventions carried out in different contexts and the increase in the knowledge and attitude results in this study, we highlight the importance of not only carrying out training sessions, but planning them based on anchoring in a theoretical framework that takes into account the previous constructions of the target audience, so that they can be truly effective and reflect in transformations that materialize in different practice scenarios, allowing for a glimpse of promising results for improving health care quality, particularly in the context of prevention and care actions in leprosy.

\section{CONCLUSION}

The educational intervention on DPD assessment in leprosy improved the knowledge and attitude of the PHC professionals, with an increase in the scores of all items in the questionnaire at the post-intervention moment; it can be inferred that significant learning occurred from the interaction between the ideas that were presented in the intervention with the pre-existing ones in their cognitive structures. Given the positive effects of the educational intervention based on the AMLT, it is suggested to offer periodic training sessions that value the professionals' prior knowledge and attitudes and their active participation in the teaching-learning process, in order to promote retention of what was learned and to advance in control of the disease and its repercussions.

Although the objective directed to the effects produced in the knowledge and attitude constructs has been successfully achieved, the duration of the concise training course is pointed out as a limitation of this study to minimize the number of absences of professionals from the FHUs, limiting practical training and non-observation of the implementation of the knowledge acquired in the professionals' routine, that is, advancement of the study into the practice.

\section{SUPPLEMENTARY MATERIAL}

The following online material is available for this article.

Link to access the complete thesis: https://repositorio.ufpb. br/jspui/handle/123456789/21030. Additional data on demand.

\section{RESUMO}

Objetivo: Analisar os efeitos de uma intervenção educativa à luz da Teoria da Aprendizagem Significativa sobre o conhecimento e a atitude de médicos e enfermeiros da atenção básica de saúde na avaliação do grau de incapacidade física na hanseníase. Método: Estudo de intervenção do tipo antes e depois, realizado com 122 profissionais, sendo 84 enfermeiros e 38 médicos, da Atenção Básica de Saúde de João Pessoa, Paraíba, em curso de capacitação sobre avaliação do grau de incapacidade física na hanseníase. Os dados foram coletados com instrumento próprio validado e analisados pelo teste qui-quadrado aderência e de proporção, com nível de significância de 5\%. Resultados: Houve aumento dos escores de todos os itens do instrumento, com diferença estatisticamente significativa $(p<0,05)$ em 20 dos 32 itens, com destaque para os itens referentes à capacidade técnica do profissional para conduzir as etapas de anamnese, palpação dos nervos periféricos, avaliação sensitiva e motora. Destaca-se também que após a intervenção 5 itens obtiveram 100\% de acertos. Conclusão: Intervenção educativa pautada na Teoria da Aprendizagem Significativa aperfeiçoou o conhecimento e a atitude dos profissionais de saúde na avaliação do grau de incapacidade física de pessoas com hanseníase.

\section{DESCRITORES}

Hanseníase; Conhecimento; Atitude; Pessoas com Deficiência; Atenção Primária à Saúde.

\section{RESUMEN}

Objetivo: Analizar los efectos de una intervención educativa a la luz de la Teoría del Aprendizaje Significativo sobre el conocimiento y la actitud de los médicos y enfermeros de la Atención Primaria de la Salud en la evaluación del grado de discapacidad física en casos de lepra. Método: Estudio de intervención antes y después, realizado con 122 profesionales, 84 enfermeras y 38 médicos, de Atención Primaria de la Salud en João Pessoa, Paraíba, en un curso de capacitación sobre la evaluación del grado de discapacidad física en lepra. Los datos se recolectaron mediante un instrumento validado y se analizaron mediante la prueba de chi-cuadrado de adherencia y proporción, con nivel de significancia del $5 \%$. Resultados: Hubo un aumento en las puntuaciones de todos los ítems del instrumento, con diferencia estadísticamente significativa ( $\mathrm{p}<0.05$ ) en 20 de los 32 ítems, con énfasis en los ítems referentes a la capacidad técnica del profesional para realizar los pasos de la anamnesis, palpación de los nervios periféricos, evaluación sensorial y motora. Además, es de destacar que luego de la intervención, 5 ítems obtuvieron respuestas 100\% correctas. Conclusión: La intervención educativa basada en la Teoría del Aprendizaje Significativo mejoró el conocimiento y la actitud de los profesionales de la salud en la evaluación del grado de discapacidad física de las personas con lepra.

\section{DESCRIPTORES}

Lepra; Conocimiento; Actitud; Personas con Discapacidad; Atención Primaria de la Salud. 


\section{REFERENCES}

1. Rosa GR, Lima MM, Brito WI, Moreira AM. Análise da completude de incapacidade em hanseníase da regional de saúde de Rondonópolis/MT. Revista Eletronica Gestão \& Saúde [Internet]. 2016 [cited 2021 Oct 15];7(1):82-95. Available from: https://periodicos.unb.br/index.php/rgs/article/ view/3390

2. Silva JSR, Palmeira IP, Sá AMM, Nogueira LMV, Ferreira AMR. Fatores sociodemográficos associados ao grau de incapacidade física na hanseníase. Revista Cuidarte. 2018;9(3):2338-48. DOI: http://dx.doi.org/10.15649/cuidarte.v9i3.548

3. Brasil. Ministério da Saúde. Secretaria de Vigilância em Saúde. Guia prático sobre a hanseníase [Internet]. Brasília; 2017 [cited 2021 Oct 15$].$ Available from: https://portalarquivos2.saude.gov.br/images/pdf/2017/novembro/22/Guia-Pratico-de-Hanseniase-WEB.pdf

4. World Health Organization (WHO). Global leprosy update, 2018: moving towards a leprosyfree world. Weekly Epidemiol Rec [Internet]. 2019 [cited 2021 Oct 15];35(94):389-412. Available from: https://www.who.int/publications/i/item/who-wer9435-36

5. Brasil. Ministério da Saúde. Secretaria de Vigilância em Saúde. Departamento de Doenças de Condições Crônicas e Infecções Sexualmente Transmissíveis. Hanseníase no Brasil - caracterização das incapacidades físicas [Internet]. Brasília; 2020 [cited 2021 Oct. 15]. Available from: http://www.aids.gov.br/pt-br/pub/2020/hanseniase-no-brasil-caracterizacao-das-incapacidades-fisicas

6. Brasil. Ministério da Saúde. Secretaria de Vigilância em Saúde. Departamento de Doenças de Condições Crônicas e Infecções Sexualmente Transmissíveis. Coordenação-Geral de Hanseníase e Doenças em Eliminação. Estratégia Nacional para Enfrentamento da Hanseníase $2019-2022$ [Internet]. Brasília; 2020 [cited 2021 Oct 17]. Available from: http://www.aids.gov.br/pt-br/pub/2020/estrategia-nacional-para-enfrentamento-dahanseniase-2019-2022

7. Oliveira SB, Ribeiro MDA, Silva JCA, Silva LN. Avaliação do nível de informação sobre hanseníase de profissionais da estratégia saúde da família. Revista de Pesquisa em Saúde [Internet]. 2017 [cited 2021 Oct 17];18:139-43. Available from: http://www.periodicoseletronicos.ufma.br/index. php/revistahuufma/article/view/8747/5901

8. Saltarelli RMF, Seixas DHT. Limites e possibilidades na atenção ao portador de hanseníase no âmbito da estratégia saúde da família. Revista de APS [Internet]. 2016 [cited 2021 Oct 17];19(4):613-22. Available from: https://periodicos.ufjf.br/index.php/aps/article/view/15557

9. Vieira NF, Rodrigues RN, Niitsuma ENA, Lanza FM, Lana FCF. Avaliação da atenção primária: comparativo entre o desempenho global e as ações de hanseníase. Revista de enfermagem do Centro Oeste Mineiro. 2019;9:e2896. DOI: http://dx.doi.org/10.19175/recom.v9i0.2896

10. Ausubel D. Aquisição e retenção de conhecimentos: uma perspectiva cognitiva. Lisboa: Plátano Edições Técnicas; 2000.

11. Brasil. Ministério da Saúde. Secretaria de Gestão do Trabalho e da Educação na Saúde. Departamento de Gestão da Educação na Saúde. Política Nacional de Educação em Saúde: o que se tem produzido para o seu fortalecimento? [Internet] Brasília; 2018 [cited 2021 Oct 17]. Available from: https://bvsms.saude.gov.br/bvs/publicacoes/politica_nacional_educacao_permanente_saude_fortalecimento.pdf

12. Marinho LAB, Gurgel MSC, Cecatti JG, Osis MJD. Conhecimento, atitude e prática do autoexame das mamas em centro de saúde. Rev Saude Publica. 2003;5(37):576-82. DOI: http://dx.doi.org/10.1590/S0034-89102003000500005

13. Moreira MA, Masini EFS. Aprendizagem significativa: a teoria de David Ausubel. 2th. São Paulo: Centauro; 2006.

14. Brasil. Ministério da Saúde. Secretaria de Vigilância em Saúde. Departamento de Doenças Transmissíveis. Diretrizes para vigilância, atenção e eliminação da hanseníase como problema de saúde pública: manual técnico operacional [Internet]. Brasília; 2016 [cited 2021 Oct 16]. Available from: https://portalarquivos2.saude.gov.br/images/pdf/2016/fevereiro/04/diretrizes-eliminacao-hanseniase-4fev16-web.pdf

15. Girão Neta OA, Arruda GMMS, Carvalho MMB, Gadelha RRM. Percepção dos Profissionais de Saúde e Gestores sobre a Atenção em Hanseníase na Estratégia Saúde da Família. Revista Brasileira de Promoção da Saúde. 2017;30(2):239-48. DOI: http://dx.doi.org/10.5020/18061230.2017.p239

16. Rodrigues FF, Calou CG, Leandro TA, Antezana FJ, Pinheiro AK, da Silva VM, et al. Knowledge and practice of the nurse about leprosy: actions of control and elimination. Rev Bras Enferm. 2015;68(2):297-304. DOI: http://dx.doi.org/10.1590/0034-7167.2015680216i

17. World Health Organization (WHO). Global Leprosy Strategy 2016-2020: Accelerating towards a leprosy-free world [Internet]. World Health Organization; 2016 [cited 2021 Oct 15]. Available from: https://apps.who.int/iris/handle/10665/254907

18. Leroy FS, Coelho ACO, Niitsuma ENA, Gomes FBF, Lanza FM, Ribeiro GC, et al. Educação permanente em saúde: a experiência do uso da educação a distância na capacitação em ações de controle da hanseníase. Unirede [Internet]. 2017 [cited 2021 Oct 16];4(1):235-50. Available from: https://www.aunirede.org.br/revista/index.php/emrede/article/view/176

19. Beluci ML, Borgato MH, Galan NGA. Avaliação de cursos multiprofissionais em hanseníase. Hansen Int [Internet]. 2012 [cited 2021 Oct 16];37(2):47-53. Available from: https://periodicos.saude.sp.gov.br/index.php/hansenologia/article/view/36195

20. Pinheiro JJG, Gomes SCS, Aquino DMC, Caldas AJM. Aptidões cognitivas e atitudinais do enfermeiro da atenção básica no controle da hanseníase. Revista Baiana de enfermagem. 2017;31(2):e17257. DOI: http://dx.doi.org/10.18471/rbe.v31i2.17257

21. Sousa ALA, Feliciano KVO, Mendes MFM. Family Health Strategy professionals' view on the effects of Hansen's disease training. Rev Esc Enferm USP. 2015;49(4):610-8. DOI: http://dx.doi.org/10.1590/S0080-623420150000400011 